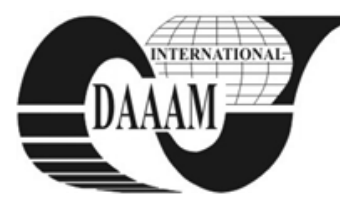

\title{
A STATISTICAL STUDY REGARDING SMILE ATTRACTIVENESS FROM PATIENT'S PERSPECTIVE
}

\author{
MUNTEAN, E[lena] A[driana]; BRATU, E[lisabeta] \& VERNIC, C[orina]
}

\begin{abstract}
Smile is one of the most important facial expressions essential in expressing friendliness, agreement and appreciation (Tjan et al. 1984). The aesthetic analysis of the smile represents an important step in the diagnosis, treatment and prognosis of any dental disease involving aesthetic objectives $^{1}$. The goal of this study is to determine the comparative perception of the smile aesthetics at the level of other persons not trained in this field. 510 persons, between 19 and 45 years old, from the Victor Babeş University of Medicine and Pharmacy, Timişoara, Department of Dentofacial Aesthetics, were analysed. The inclusion/exclusion criteria were predefined for this study. Two persons not trained in this field rated then the attractiveness of the smile of patients on a scale from 1 to 4. A database was created in Microsoft Excel and a statistical analysis was performed. At the level of the questioned persons, for the ratings of $2(p=0.017497 \mathrm{~S})$ and 3 $(p=0.024934 S)$ there were significant opinion differences from an aesthetical point of view. The aesthetic references studied are offered for guidance and have to consider that each person is unique in its own way. Regardless of the clinical state, the most important thing remains restoring proper functionality, and aesthetics will never be considered a top priority in the detriment of function.
\end{abstract}

Key words: aesthetic perception, smile, incisal edge, dental midline

\section{INTRODUCTION}

The orthodontic literature contains more studies on skeletal structure than on soft-tissue structure, and the smile still receives relatively little attention(Farkas et al.,1984). The way in which patients perceive their own smile while watching themselves in the mirror differs a great deal from the way in which the orthodontist analyses the position of teeth in occlusion using mouth spreaders(Patnaik et al., 2003). This is why, for a proper aesthetic analysis it was proposed that, when taking a photograph with the smile of the patients, the head of the patient has to be in a normal position, looking in front, towards a distant point(Moore et al., 2005; Flores Mir et al., 2003; Ackerman et.al, 2002). To capture a natural, free smile of the patient, several photographs will be taken, out of which the one that best corresponds to the real situation will be selected, more precisely that of the natural smile(Farkas et al., 1984; Goldstein et al., 1998).

\section{MATERIAL AND METHOD}

The study was made on a group of 510 persons, of which 375 women and 135 men, with ages between 19 and 45, from the Victor Babes University of Medicine and Pharmacy, Timişoara, Department of Aesthetic Dentistry, all having permanent dentition. Those who had or were having an orthodontic treatment were excluded from the study. The persons with different degrees of anomalies, malformations or surgeries for facial scars, clefts, etc. were also excluded. The presence of the wisdom teeth was not taken into consideration in determining the type of dentition. In order to do this, the photographs chosen from a set of several entries, which best represented the natural smile, were aesthetically analysed.

Two persons not trained in this field analysed each photograph based on the attractiveness of the smile, by rating them on a scale from 1 to 4 as follows:

- Pleasant smile 1

- Quite pleasant smile2

- Quite unpleasant smile3

- Unpleasant smile 4

The statistical analysis of the data was made on a computer, based on the file created in Microsoft Excel with specialised software: SPSS 10, OpenEpi and Epi Info 6.04.

\section{RESULTS AND DISCUSSION}

The group comprised 385 females representing $75,5 \%$ and 125 males representing $24,5 \%$ with middle ages of $23,73+/$ $3,416(19,45)$. The detofacial analysis showed a convex curve of the incisal edge to lower lip, considered the ideal situation in $47,1 \%$ of cases and straight incisal edge to lower lip in 45,3\% of cases. The concave curve of the incisal edge was observed in $6,1 \%$ of cases and a covered incisal edge was shown I 1,6\% of cases. The upper lip was high in $56,7 \%$ of cases, average in $36,1 \%$ of cases and low in $7,3 \%$ of cases.

Most of the patients exposed during smiling between 6 and 8 teeth wich can be the result of shy nature of people in front of camera and the dental midline was centered in $59 \%$ of cases with the facial midline. The results are presented in table 1 and graphically in fig. 1, 2, 3 and 4 .

\begin{tabular}{|c|c|c|c|c|}
\hline $\mathrm{Nr}$ & Parameter & Observation & Frec & Percent \\
\hline \multirow{4}{*}{1} & \multirow{4}{*}{$\begin{array}{l}\text { Incisal edge } \\
\text { to lower lip }\end{array}$} & $\begin{array}{l}\text { Convexe } \\
\text { curve(A) }\end{array}$ & 240 & $47,1 \%$ \\
\hline & & Straight $(\mathrm{B})$ & 231 & $45,3 \%$ \\
\hline & & $\begin{array}{l}\text { Concave } \\
\text { curve }(\mathrm{C})\end{array}$ & 31 & $6,1 \%$ \\
\hline & & Covered(D) & 8 & $1,6 \%$ \\
\hline \multirow{3}{*}{2} & \multirow{3}{*}{ Upper lip } & Average(E) & 184 & $36,1 \%$ \\
\hline & & $\operatorname{High}(\mathrm{F})$ & 289 & $56,7 \%$ \\
\hline & & $\operatorname{Low}(\mathrm{G})$ & 37 & $7,3 \%$ \\
\hline \multirow{3}{*}{3} & \multirow{3}{*}{$\begin{array}{l}\text { Number of teeth } \\
\text { exposed during } \\
\text { smiling }\end{array}$} & $6-8(\mathrm{H})$ & 351 & $68,8 \%$ \\
\hline & & $9-11(\mathrm{I})$ & 117 & $22,9 \%$ \\
\hline & & $12-14(\mathrm{~J})$ & 42 & $8,2 \%$ \\
\hline \multirow{3}{*}{4} & \multirow{3}{*}{$\begin{array}{l}\text { Midline relation } \\
\text { of central } \\
\text { incisors to facial } \\
\text { midline }\end{array}$} & Centered $(\mathrm{K})$ & 301 & $59 \%$ \\
\hline & & $\begin{array}{l}\text { Right of center } \\
\text { (L) }\end{array}$ & 152 & $29,8 \%$ \\
\hline & & $\begin{array}{l}\text { Left of center } \\
\text { (M) }\end{array}$ & 57 & $11,2 \%$ \\
\hline
\end{tabular}

Tab. 1. Presents the results of the dentofacial analysis 


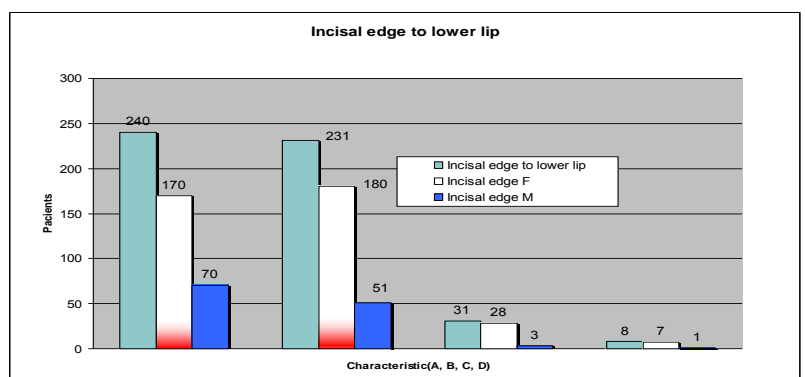

Fig. 1 presenting the distribution of the incisal edge to lower lip during smiling among sexes

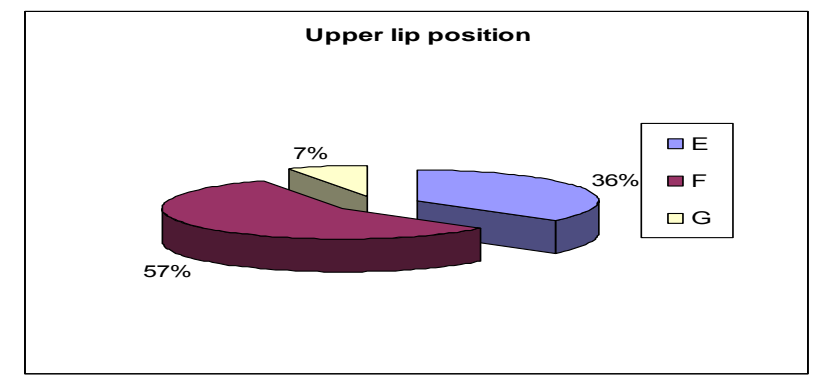

Fig.2 Presenting perceptual distribution of upper lip position

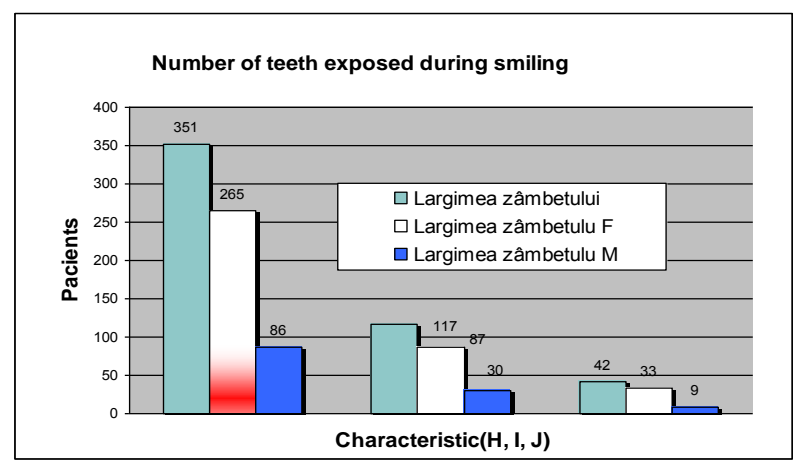

Fig.3 Presents the distribution among sexes of the number of teeth exposed during smile

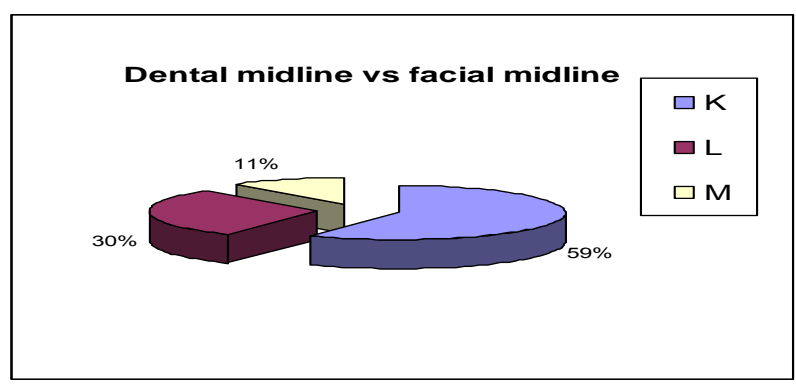

Fig. 4. The procentual distribution of midlinie position

Among the persons questioned, for the ratings of 2 ( $\mathrm{p}=$ $0.017497 \mathrm{~S})$ and $3(\mathrm{p}=0.024934 \mathrm{~S})$ there were significant opinion differences from a statistical point of view (Table 2). This proves that beauty is relative, and that what one person considers aesthetic, the other may consider less attractive.

\begin{tabular}{|l|l|l|l|l|l|l|}
\hline & Frecv. & Procent & Frecv. & Procent & $\mathrm{p}$ & Semnificaţia \\
\hline 1 & 206 & 40,4 & 209 & 41,0 & 0.848358 & NS \\
\hline 2 & 217 & 42,5 & 180 & 35,3 & 0.017497 & S \\
\hline 3 & 74 & 14,5 & 101 & 19,8 & 0.024934 & S \\
\hline 4 & 13 & 2,5 & 20 & 3,9 & 0.215439 & NS \\
\hline Total & 510 & 100,0 & 510 & 100,0 & & \\
\hline
\end{tabular}

Tab. 2. The results of the statistical comparative analysis P1 -P2

\section{CONCLUSIONS}

It still is unclear how laypeople evaluate smile esthetics(Parekh et al., 2006). There are many potential distracters and interactions among different smile characteristics. Substantial variability is reported in the existing literature on this topic.

The components of the smile should be considered not as rigid boundaries, but as artistic guidelines to help orthodontists treat individual patients who are today, more than ever, highly aware of smile esthetics.

\section{REFERENCES}

Ackerman MB, Ackerman JL.(2002) Smile analysis and design in the digital era. J Clin Orthod. Apr;36(4):221-36

Cunningham, M. (1986) : Measuring the physical in physical attractiveness : Quasi-experiments on the sociobiology of female facial beauty. Journal of Personal \& social Psychology.50:925-35

Farkas LG, Katic MJ, Hreczko TA, Deutsch Curtis, Munro IR. (1984) Anthropomeric proportion in the upper lip- lower lip-chin area of lower face in white young adults Am J Orthod ; 82; 52-60

Flores-Mir C., Silva E., Barriga M. I., Lagravère O. and Major P. W., (2004) Lay person's perception of smile aesthetics in dental and facial views, Journal of Orthodontics, September, 31(3), 204-209

Geron S, Atalia W. (2005) Influence of sex on the perception of oral and smile esthetics with different gingival display and incisal plane inclination. Angle Orthod ;75(5):778-784.

Goldstein, R.E. (1998) Esthetics in Dentistry 2nd Edn. Vol-1. Decker,Toronto

Garber DA, Salama MA. (1996)The aesthetic smile: Diagnosis and treatment. Periodontol 1996; 11:18-28

Gracco A, Cozzani M, D'Elia L, Manfrini M, Peverada C, Siciliani G. (2006) The smile buccal corridors: aesthetic value for dentists and laypersons. Prog Orthod ;7(1):56-65

Kim HS, Kim IP, Oh SC, Dong JK. (1995)The effect of personality on the smile. J Wonkwang Dent Res Instit ; 5: 299-314

Moore T, Southard KA, Casko JS, Qian F, Southard TE.(2005) Buccal corridors and smile esthetics. Am J Orthod Dentofacial Orthop; 127(2):208-213; quiz 261

Parekh SM, Fields HW, Beck M, Rosenstiel S. (2006) Attractiveness of variations in the smile arc and buccal corridor space as judged by orthodontists and laymen. Angle Orthod ;76(4):557-563

Patnaik VVG, Singla R, Bala S(2003) Anatomy of a beautiful face and smile, J Anat Soc Ind ; 52(1); 74-80

Patnaik VVG , Archana Goel(2010) Lip Morphometry and dentofacial analysisbased data for personal identification \& forensic significance- a study in 250 Indian adults JINPAFO Vol 1, Jan

Peck S, Peck H. (1971) The aesthetically pleasing face: An orthodontic myth. Trans Eur Orthod Soc ; 47: 175-185

Ritter DE, Gandini LG Jr, Pinto AS, Ravelli DB, Locks A (2006),Analysis of the smile photograph, World J Orthod; 7(3):279-85

Sarver DM, Ackerman MB.(2003) Dynamic smile visualization and quantification: Part-2. Smile analysis and treatment strategies. Am J Orthod Dentofac Orthop ; 124: 116-127

Tjan A.H.L., Miller G.D., The J.G.P(1984), Some esthetic factors in a smile,Journal of Prosthetic Dentistry,51:24-48

Zachrisson BU.(1998) Esthetic factors involved in anterior tooth display and smile: vertical dimension. J Clin Orthod. ;32(7):432-45 